Tijdschr Urol (2021) 11:75

https://doi.org/10.1007/s13629-021-00332-z

\section{Goed kijken}

\author{
Henk G. van der Poel
}

Geaccepteerd op: 21 juni 2021 / Published online: 7 juli 2021

(C) The Author(s) 2021

We worden als urologen zo af en toe verrast. Is een volle blaas nu altijd retentie of moet de differentiaaldiagnose misschien nog iets anders bevatten? Naast een groot blaasdivertikel bij de man of de grote ovariumcyste bij de vrouw voegen Mensink, Zijta en Tong daar nu ook de utriculuscyste aan toe, een interessante casus in dit nummer.

Daarnaast in dit nummer een analyse van de vraag of de SelectMDX-urinetest in de eerste lijn zou kunnen worden ingezet, en hoe dan. Laten we vooral ook denken aan de Prostaatwijzer die, voorafgaand aan welke diagnostische test dan ook, al veel informatie kan geven over (significante) prostaatkankerrisico's en die, naar mijn weten, nog nauwelijks in de eerste lijn wordt ingezet. Sommige huisartsen merken in dit onderzoek op dat de urinetest wel heel specialistische zorg is, die weleens meer bij de uroloog zou kunnen thuishoren. Ik ben dat eigenlijk wel met hen eens: de test kan dan relatief eenvoudig worden uitgevoerd, de uitslag en de hierbij behorende consequenties voor de patiënt zijn niet zonder meer te vertalen in een een- duidig medisch advies. Kennis van zake blijft hierbij belangrijk voor het maken van een goede weging hoe verder te gaan.

Tot slot een mooi overzicht van de rol van de PSMAPET bij recidief prostaatkanker: in $24-69 \%$ van de gevallen beïnvloedde de PET-resultaten de behandelkeuze. Met name bij mannen na een prostatectomie en positieve klierdissectie veranderde het beleid (69\%) nadat de resultaten van de PSMA PET-scan bekend werden. Niet verwonderlijk dus dat de richtlijnen de PSMA PET nu adviseren als eerste keus bij recidief ziekte.

Open Access This article is distributed under the terms of the Creative Commons Attribution 4.0 International License (http://creativecommons.org/licenses/by/4.0/), which permits unrestricted use, distribution, and reproduction in any medium, provided you give appropriate credit to the original author(s) and the source, provide a link to the Creative Commons license, and indicate if changes were made.

prof. dr. Henk G. van der Poel, hoofdredacteur 